Науменко Н. Ю., кандидат технічних наук, доцент, доцент кафедри теоретичної та прикладної економіки, Державний вищий навчальний заклад «Український державний хіміко-технологічний університет», м. Дніпро, Україна

ORCID ID: 0000-0002-0585-932X

e-mail: nata.yu.naumenko@gmail.com

\title{
Особливості конкретизації методології формування інформаційного простору регіональних соціально-економічних систем
}

\begin{abstract}
Анотація. В статті економічна безпека регіональних соціально-економічних систем розглядається як сукупність заходів забезпечення збалансованої економічної та інвестиційної привабливості регіону з урахуванням протидій зовнішнім та внутрішнім загрозам. На життєдіяльність украӥнського суспільства в сучасних умовах дедалі більший вплив здійснюють інформаційні процеси. В роботі проаналізовано дослідження вчених щодо проблем забезпечення безпеки на національному та регіональному рівнях та методології формування інформаційного простору на рівні регіону, наголошено на відсутності наукового визначення поняття єдиного інформаційного простору. Автором запропонована укрупнена логічна схема руху інформаційних потоків та всіх рівнях інформаційного простору (світовий інформаційний простір - національний інформаційний простір регіональний інформаційний простір - інформаційний простір суб'єктів господарської діяльності регіональних промислового та інфраструктурного комплексів). В статті представлена концепт-модель структури інформаційного простору, яка відображає предметно-орієнтовану інформаційну систему обробки інформації. Встановлено, що проблема формування та розвитку єдиного інформаційного простору регіону потребує розробки та адаптації відповідного науково-методологічного забезпечення в напрямку інформаційної безпеки регіональних соціально-економічних систем. Виділено декілька підходів дослідження інформаційного простору в межах формування методологічних положень інформаційного простору регіональних соціально-економічних систем: територіальний, функціональний, еволюційний. На основі запропонованих підходів виділено в якості єдиного із пріоритетних напрямів інформатизації регіонів України утворення єдиного структурованого інформаційного простору для забезпечення процесу децентралізації в межах регіональних соціально-економічних систем. Концептуальну модель інформаційного простору регіональної соціально-економічної системи представлено сукупністю компонентів.
\end{abstract}

Ключові слова: економічна безпека регіону; інформаційно-комунікаційні технологї; інформаційна безпека; інформаційний простір.

Naumenko N. Yu., PhD in Engineering, Associate Professor, Associate Professor of Department of Theoretical and Applied Economics, State Higher Education Institution "Ukrainian State University of Chemical Technology", Dnipro, Ukraine

\section{Specifics of the Methodology of Formation of the Information Space in Regional Socio-Economic Systems}

Abstract. Introduction. The article considers the economic security of regional socio-economic systems as a set of measures to ensure a balanced economic and investment attractiveness of the region, taking into account the counteraction to external and internal threats. Today, information processes are increasingly influencing the life of Ukrainian society.

Purpose. The paper analyses the published research on the problems of security at the national and regional levels; it studies the problems of the methodology of the information space formation at the regional level and reveals the lack of a strictly scientific definition for the single information space concept.

Results. The author proposes an integrated logic information flow chart for all levels of the information space (world information space - national information space - regional information space - information space of economic entities that are part of regional industrial and infrastructural complexes). The article presents a conceptual model of the information space structure, which reflects the object-oriented information system of data processing. It has been established that the problem of formation and development of the single information space in a region requires the development and adaptation of the relevant scientific and methodological support in the sphere of information security of regional socio-economic systems. Several approaches to the study of information space, such as the territorial, functional, and evolutionary approaches, have been identified within the framework of the formation of methodological provisions for the information space of regional socio-economic systems. Based on the proposed approaches, the formation of a single structured information space for ensuring the process of decentralization within regional socio-economic systems has been identified as one of the priority directions of informatisation of the regions in Ukraine. The conceptual model of the information space of a regional socio-economic system has been represented by a set of components, i.e. agents of the information space (information systems), the agents' mental models of the external environment and themselves in the form of information resources and the nature of the informational interaction between the agents within the specified space.

Стаття надійшла до редакції: 25.04.2019

Received: 25 April 2019 
Conclusions. In the author's opinion, it is necessary to continue the investigation of methodological aspects of the formation of information resources and information space in regional socio-economic systems.

Keywords: economic security of the region; information and communication technologies.

JEL Classification: B 49, D 89, 0 18, R 58.

Постановка проблеми. Як показує світовий досвід, забезпечення економічної безпеки - це гарантія самодостатності, незалежності держави та її регіонів, умови стабільності та ефективної життєдіяльності населення, досягнення економічного розвитку. Проблематика забезпечення економічної безпеки України та іï регіонів як умова ії відродження приваблюють до себе все більш пильну увагу політичних діячів, вчених-економістів, самих широких прошарків населення.

В межах загального підходу економічна безпека являє собою сукупність умов і факторів, що характеризують поточний стан економіки, стабільності, стійкості, збалансованості та поступовості іiі розвитку. Економічна безпека традиційно розглядається як найважливіша якісна характеристика функціональних економічних систем (далі - ФЕС), які визначають їх здатність підтримувати нормальні умови життєдіяльності населення, стійке забезпечення ресурсами народного господарства, а також послідовну реалізацію національно-державних інтересів.

Економічна безпека регіонів (далі - ЕБР) - комплекс заходів, які напрямлені на стійкий, збалансований, постійний розвиток та вдосконалення економіки та інвестиційної привабливості регіону, що обов'язково передбачає механізм протидії зовнішнім та внутрішнім загрозам. В комплексі заходів, які формують систему ЕБР, визначне значення повинно приділятись запобіганню загроз, що зароджуються.

3 позиції ЕБР важливо оцінювати та прогнозувати вплив всіх очікуваних загроз, а також економічних та неекономічних впливів на їх перебіг, а головне виявляти можливість різкого спаду та критичного порогу. Одночасно з прогнозно-аналітичною виникає й обернена задача, яка полягає в розробці та реалізації системи інформаційного простору, що спрямоване на недопущення кризи, як на макро-, мезо- та мікрорівнях.

В сучасних умовах на життєдіяльність українського суспільства дедалі більший вплив здійснюють інформаційні процеси. Слід зазначити, що в межах ЕБР інформаційна система, як правило, організовується в якомусь наявному (наприклад, регіональному) інформаційному просторі, приймаючи його властивості та правила роботи, вона системно генерує свій інформаційний простір, який додає певну функціональність «регіональному» простору, змінюючи або доповнюючи його властивості.

Ефективність функціонування будь-якої інформаційної системи (IC) безпосередньо пов'язана з тим, як організовані розміщення, зберігання, пошук та обробка інформації. Очевидно, що ефективне управління можливо тільки в тій системі, в якій чітко визначені інформаційні зв'язки як між окремими елементами, так і з зовнішнім середовищем. В цьому випадку забезпечується можливість координації діяльності різних підсистем, їх сполучення з системами вищого або нижчого рівня.

Необхідність уточнення теоретичної моделі будьяких систем (макро-, мезо-, мікрорівнів) з урахуванням інформаційного фактора пов'язана, з одного боку, 3 розвитком інформаційно-комунікаційної технології (IKT), що обумовлюють зміни інформаційних взаємодій в суспільстві, а іншого - фундаментальні основи теорії недостатньо досліджують відображення в інформаційному просторі взаємодій між суб'єктами будь-якої діяльності. В традиційному уявленні сучасні теорії як регіональної економіки, так і економічної безпеки, мають не в достатній мірі опрацьовану базу для повноцінного дослідження змін, які відбуваються в суспільстві під впливом процесів глобальної економіки, підвищення інтенсивності та розширення масштабів інформаційних взаємодій, комунікацій.

Аналіз останніх досліджень і публікацій. До недавнього часу інформаційні комунікації в Україні та iï регіонах розглядались головним чином як засіб командно-адміністративного регулювання поточної соціально-економічної та виробничо-технікотехнологічної діяльності господарських систем на макро-, мезо- та мікрорівнях. Проблеми забезпечення економічної безпеки на національному рівні розглядалось в роботах 3. Варналія, В.Горбуліної, В. Домарева, А. Івашко, Я. Жаліло, Д. Зегжда, В. Казачка, А. Качинського, О. Новікової, А. Петракова, В. Предборського, В. Сизоненка, А. Сухорукова, Ю. Харазішвілі та ін.

Проблемами методології формування інформаційного простору на рівні регіонів присвячені роботи вітчизняних вчених: В. Геєця, А. Дудатьєва, М. Кизима, Т. Клебанової, Г. Корниченко, Д. Михайлова, Ю. Радіонова, О. Резикова, Т. Ковальчук, Ю. Харазшвили, В. Черевко, О. Черняка та ін.

Формулювання цілей дослідження. Метою даного дослідження $€$ виявлення та удосконалення конкретизації методології формування інформаційного простору регіональних соціальноекономічних систем.

Виклад основного матеріалу дослідження. Сучасний розвиток глобальної економіки характеризується все більшою залежністю світових ринків та світового суспільства від значного обсягу інформаційних потоків. Слід зазначити, що попри дедалі більші зусилля по створенню технологій захисту даних, їх вразливість не тільки не зменшується, але й постійно зростає. Тому актуальність проблем 
формування інформаційного простору, а також, пов'язаних з захистом потоків даних та забезпеченням інформаційної безпеки на макро-, мезо- та мірорівнях, все більше посилюється.

При дослідженні проблем інформаційної безпеки, спеціалісти в області економічних наукових напрямків [1, с. 13] використовують методику побудови моделей, що містять побудову моделей внутрішніх та зовнішніх порушників інформаційної безпеки, побудову моделей формування системи вихідних даних для оцінки та оптимізації інформаційної безпеки та розробку математичної моделі оцінки ефективності системи інформаційної безпеки, розробку імітаційної моделі функціонування системи інформаційної безпеки для різних просторових рівнів (від мета- до нано- інформаційного простору). На думку автора праці [2, с. 72-74], дослідники у сфері економічних аспектів інформаційної безпеки до основних задач дослідження проблематики формування інформаційного простору, інформаційної безпеки на всіх рівнях відносять формування нових підходів до поняття інформації та дослідження феномену інформації як економічного ресурсу в межах макро-, мезо- та мірорівнях, адаптація основних положень теорії інформаційної безпеки для економічних напрямів досліджень та дослідження інформаційної складової виробничих відносин в умовах господарської діяльності та соціально-екологічної діяльності в межах територіального простору. До важливих задач, що розв'язуються економічними науковими напрямками у сфері інформаційної безпеки інформаційного простору, також відноситься створення методик оцінки вартості інформації.

Дослідник В. В. Немиткина виділяє окрему категорію задач, що пов'язані з ризиками та загрозами інформаційної безпеки, які містять класифікацію економічних загроз інформаційної безпеки та систематизації інформаційних ризиків [3]. Таку точку зору підтверджують для умов формування інформаційного простору на макро-, мезо-, мікрорівнях Н. В. Буханцева [4], А. Н. Баутов [5], С. А. Петренко, С. В. Симонов [6], А. М. Дубров, Б. А. Лагоша, Е. Ю. Хрусталева, Т. П. Барановская [7], А. В. Дудатьев [9].

Ряд дослідників, серед них А С. Саввін [10], Д. В. Михайлов [11], В.В.Домарев [12] виділяють в окрему категорію задачі формування інформаційного простору, що пов'язані з ризиками та загрозами інформаційної безпеки, які містять класифікацію економічних загроз та оцінку процесу гармонізації економічних інтересів регіону (локальних територій), бізнесу (суб'єктів господарської діяльності, які відбуваються на території регіонального соціальноекономічної системи) та населення регіонального економіко-інформаційного простору.

На думку автора даного дослідження, в межах виявлення особливостей конкретизувати методології формування інформаційного простору регіональних соціально-економічних систем, слід виділити проблеми дослідження інформаційної безпеки, яка пов'язана з використанням економіко-математичних методів у сфері забезпечення інформаційної безпеки у сфері економічної безпеки регіонів, а також використання інформаційних систем, як засобів конкурентних переваг та засиль значущості інформаційних ресурсів в економіці на макро-, мезота мікрорівнях.

Також важливо розуміти обгрунтування поняття, що інформаційні взаємодії відбуваються між суб'єктами, що розподілені по інформаційному простору регіональної соціально-економічної системи будь-якої складності. В інформаційному просторі (макро-, мезо- та мікрорівня) завжди є суб'єкт, який визначає межі свого інформаційного простору у вигляді різноманітних зв' язків (інформаційних потоків) суспільних, соціальних, інформаційних суб'єктів. На рис. 1 представлена укрупнена логічна схема руху інформаційних потоків на всіх рівнях інформаційного простору (світовий інформаційний простір національний інформаційний простір - регіональний інформаційний простір - інформаційний простір суб'єктів господарської діяльності регіональних промислового та інфраструктурного комплексів.

Сутність поняття «інформаційний простір» внутрішньо містить виділені аспекти територіального, функціонального, системного та еволюційного підходів. Спочатку поняття «інформаційний простір» з'явився в термінології спеціалістів різних сфер діяльності в 1992 році [4, с. 377]. Строго наукового визначення поняття єдиного інформаційного простору ще й досі не запропоновано, хоча словосполучення «інформаційний простір» в різних смислових інтерпретаціях достатньо широко. На рис. 1 представлена укрупнена логіко-системна схема руху інформаційних потоків на макро-, мезо- та макрорівнях (ілюстративна модель національного, регіонального інформаційного простору в рамках світового інформаційного простору).

В роботі А. Е. Калиніної [13] вказано, що комунікацію можна розглядати з точки зору взаємодії об'єктів, що призводить до зміни знань хоча б одного 3 них, тобто $€$ «інформаційне середовище», «інформаційний простір» $\epsilon$ поняттям динамічним. Спектр інформаційних та комунікативних взаємодій надзвичайно широкий. Академік Н. А. Кузнецов у своєму дослідженні [14, с. 111] виділяє інформаційні взаємодії в технічних системах, інформаційні взаємодії «живий організм - штучний об'єкт», «людина і машина», інформаційні взаємодії в межах від молекулярного рівня до рівня соціальних спільнот. При такому різноманітті взаємодіючих об'єктів та суб'єктів задача їх адекватного інформаційного відображення (наприклад, в межах регіональних соціально-економічних систем) представляється, як мінімум, багатосторонньою. 


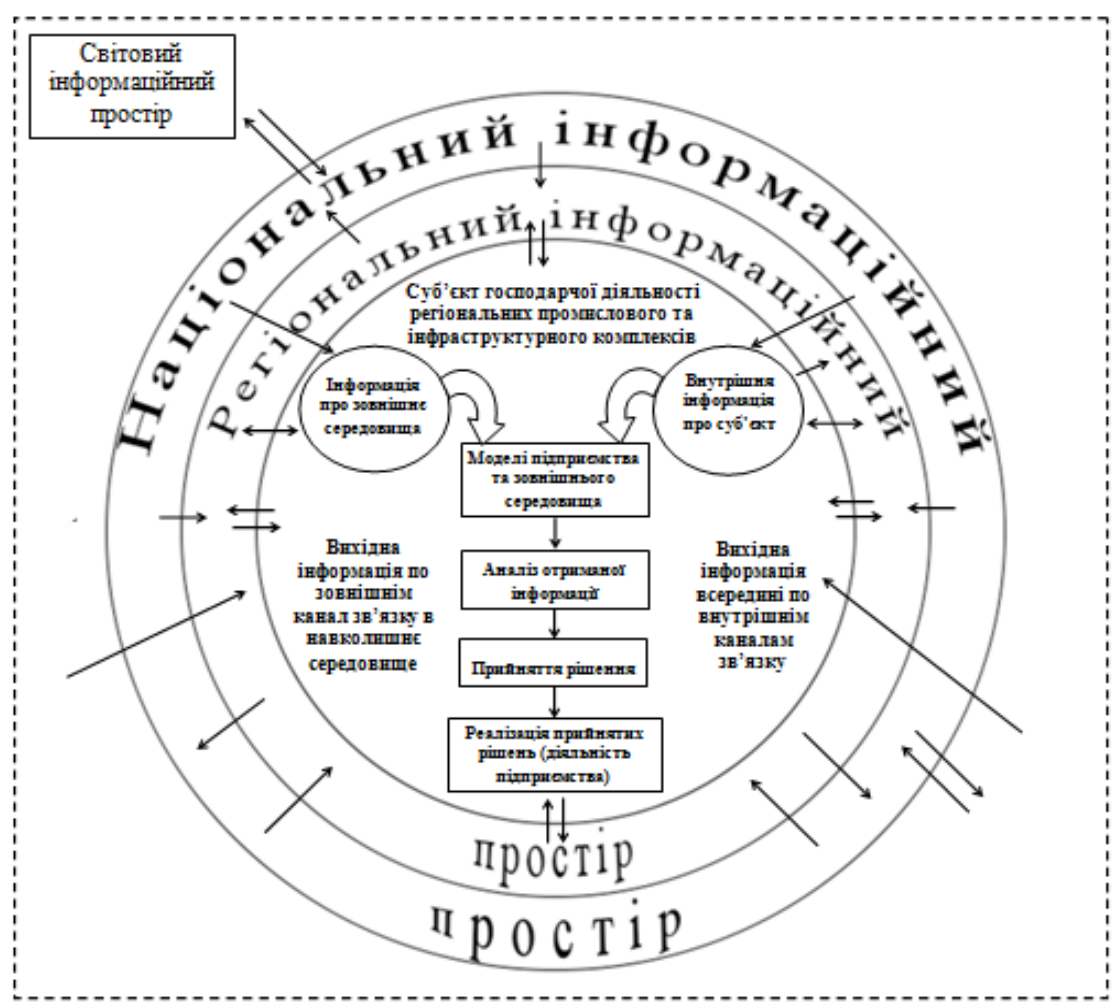

Рисунок 1 - Укрупнена логічна схема руху інформаційних потоків на мега-, макро-, мезо-, міні рівнях

Джерело: авторська розробка

Як показано на діаграмі Дж. Венна (рис. 2), предметно-орієнтована інформаційна система обробки інформації будь-якої комбінації

допомогою цієї технології існує для підтримки інформаційних технологій і діяльності людей за операцій, управління та прийняття рішень при накладенні певних компонентів інформаційного простору та їх аналітичного представлення.

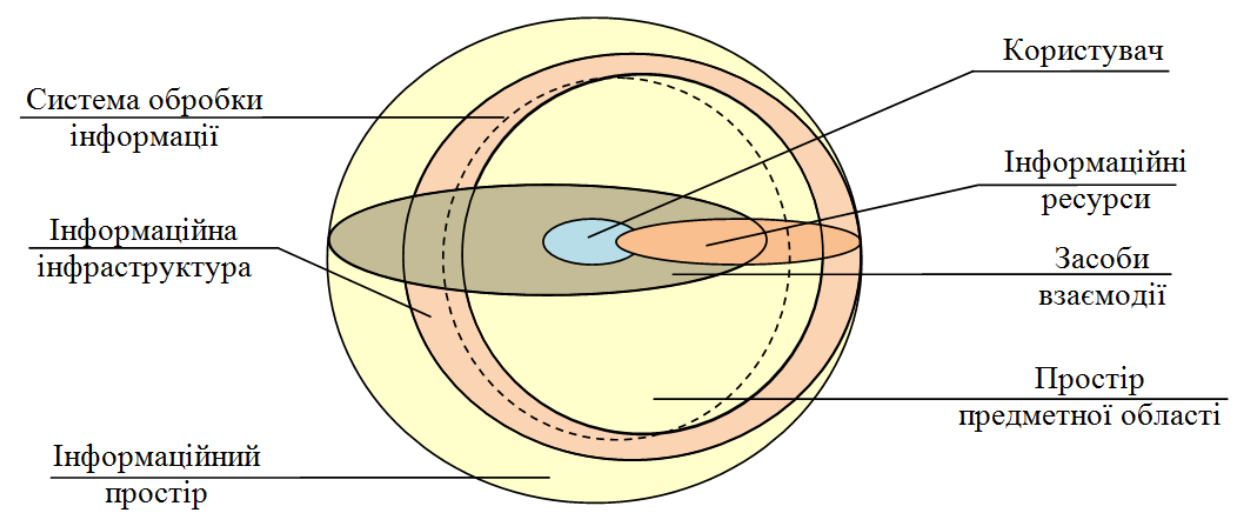

Рисунок 2 - Концепт-модель структури інформаційного простору (модифікований варіант)

Джерело: авторська розробка

3 рис. 2 очевидно, що важливе значення у рамках формування структури інформаційного простору відіграють динамічні зміни елементів інформаційного простору соціально-економічної системи. По-перше, якість та збалансованість потенціалу «інформаційної інфраструктури», як важливі складові регіонального інфраструктурного комплексу. По-друге, динаміка зміни засобів взаємодії у використанні та ефективності інформаційних ресурсів у рамках рівня розвитку IKT.

В роботі [4, с. 375] підкреслюється, що в теорії систем та системного аналізу практично відсунуті дослідження, які пов'язані з використанням поняття простору як нової системної категорії. Аналіз робіт по теорії систем моделювання економічних систем, інформаційному простору, наприклад А. П. Левича 
[15], А. Б. Антопольського [16], Д. Хімельблау [17] та ін., показує, що близьким за змістом поняття простору $€$ внутрішнє та зовнішнє середовище. Автор згоден 3 точкою зору Е. А. Азроянца, що саме поняття системи передбачає, що вона має межі та існує як об'єкт в навколишньому зовнішньому середовищі, яке виступає як екзогенний системоутворювальний фактор і саме ж середовище може розглядатися як сукупність умов діяльності, частина деяких макро-, мезо- систем, що охоплює розглянуту систему. Поняття середовища може бути застосовано, коли дослідження зосереджено на системі, яку вона оточує: середовище - система [18, с. 10, с. 12]. Водночас, автор роботи [13] відмічає, що якщо середовище регіональних соціально-економічних систем (РСЕС) містить сукупність рівнозначних систем, що виникає питання про «ресурсоємність» середовища та його межі (національне середовище, регіональне середовище, середовище РСЕС), про кількість таких систем та їх взаємне розташування. Поняття про межі середовища (мезосередовище як частини макросередовища), його розміри та позиціювання в ній компонентів елементів - систем відносяться до питань типології систем та використовують в просторових моделях об'єктів різної природи [13].

Інформація, як невід'ємна властивість матерії, $\epsilon$ основним системоутворювальним фактором, який забезпечує функціонування простору. Кожний об'єкт в інформаційному просторі РСЕС виступає як модель, що відображає інформаційні зв'язки та відносини всередині системи. Ефективність розвитку системи (наприклад РСЕС) багато в чому забезпечується за рахунок інтенсивності інформаційного обміну та залежить від характеристики та ум розповсюдження потоків інформації в просторі. В процесі обміну відбувається збільшення інформації за рахунок кросвзаємодії інформаційного фактора їх суб'єктів, і, отже, можна зробити висновок про незворотний характер зростання інформації як умови і результату еволюції систем.

Походження змін в інформаційній інфраструктурі, як важливої компоненти регіональної інфраструктури, пов'язані з еволюцією та розвитком інформаційних технологій, приводять до змін в системі, яка забезпечує функціонування інформаційного простору, в тому числі в контексті забезпечення інформаційної безпеки у сфері економічної безпеки регіону.

Автор згоден зі спеціалістами у сфері економічної безпеки, що проблема формування та розвитку єдиного інформаційного простору регіону потребує розробки та адаптації відповідного науковометодологічного забезпечення в т.ч. В напрямку інформаційної безпеки РСЕС, а також розв'язання організаційних, економічних та правових проблем інтеграції розрізнених баз даних в єдину систему. Для розв'язання цієї проблеми необхідно, зокрема, доповнити вивчення теоретико-методологічних основ інформаційного простору РСЕС комплексною методологією його аналізу, з урахуванням специфіки конкретного регіону, дослідженням можливостей механізмів інформаційного забезпечення в удосконаленні діяльності суб'єктів 3 урахуванням специфіки розвитку підсистеми регіонального рівня.

В межах формування методологічних положень інформаційного простору РСЕС має значення виділити декілька різних визначних підходів до визнаяення змісту інформаційного простору. Перший підхід територіальний - трактує інформаційний простір як «інформаційну траєкторію», тобто насичене метричне. Категорія "простір» характеризує всі основні форми руху матерії: механічну, спеціальну і т.п. Інформаційний простір РСЕС слід розглядати як територію охоплену інформацією, інформаційними ресурсами та інфраструктурою регіону, в межах якого всі суб'єкти (див. рис. 1) мають однакові можливості отримання, передачі та всіх інших маніпуляцій 3 інформацією в будь-якій точці цього простору. Таким чином, В територіальному значенні поняттям «інформаційний простір РСЕС» визначається виділена суб'єктом за будь-яким критерієм територія, на якій розташовуються інформаційні ресурси (рис. 2), джерела інформації, технологічні системи збору, обробки та розповсюдження інформації, а також користувачі різних видів ресурсів, що підпадають під юрисдикцію законодавства, що діє на цій території.

Також можливо виділення другого підходу до розкриття сутності інформаційного простору функціонального, який характеризує його як простір певних інформаційних взаємодій в межах РСЕС, тобто як динамічно предметно-орієнтована інформаційна система, яка володіє інтегративними властивостями в залежності від ієрархії та структуризації за рахунок систем (підсистем) аналітичної обробки інформації та можливостей забезпечення доступу до неї (інформаційний захист) різних груп користувачів. Даний підхід отримав розвиток в концепції формування єдиного інформаційного простору (для макро- та мезорівнів) і, відповідного йому функціоналу інформаційних ресурсів.

На думку автора даного дослідження, утворення єдиного структурованого інформаційного простору для забезпечення процесу децентралізації в межах РCEC - одне з пріоритетних напрямків інформатизації регіонів України, яке сприяє утворенню інформаційного простору як в регіоні так і в державі, а також утворенню умов забезпечення економічної безпеки регіонів. Реалізація даного напрямку інформатизації також $є$ необхідною умовою стійкого розвитку в межах конкретної території.

Третій підхід аналізу поняття інформаційного простору РСЕС, як еволюційного, визначається В процесі переробки, аналізу інформації. Суб'єкти інформаційного простору в умовах функціонування PCEC сприймають зовнішнє середовище шляхом фільтрації, переробки та аналізу інформації за допомогою поточних інформаційних (ментальних) 
моделей, які забезпечують розуміння зовнішнього середовища, і розв'язання проблем, що виникають. На думку автора, концептуальну модель інформаційного простору РСЕС можна представити сукупністю компонентів, причому чим точніше інформаційна модель відображає зміст та функції простору, тим більше потенціал ефективної діяльності його суб'єктів, учасників РСEC, що забезпечується принципом відповідності інформаційного простору іншими його функціональними факторами.

Інформатизація управління в умовах функціонування РСЕС - стійкий процес, об'єктивно існуючий i, не зважаючи на всі складності, розвиваються на протязі останніх років. Існують керівники органів регіональної влади, топ-менеджери суб'єктів господарської діяльності в межах РСЕС, які приймають ті чи інші управлінські рішення, також є інформаційнокомунікаційна інфраструктура системи управління PCEC і $є$ безліч об'єктів, які потребують керування. Все це пронизане рухом інформаційних потоків в інформаційних просторах на макро-, мезо- та макрорівнях, що генеруються інформаційними системами різної організаційно-економічної складності.

Висновки. Економічні наукові напрямки в методологічному аспекті відіграють велику роль у розв'язанні проблеми інформаційної безпеки в сфері забезпечення економічної безпеки на рівні PCEC. Забезпечення безпеки інформаційних систем в межах PCEC безпосередньо інформаційних ресурсів РСЕС та формування умов для інформаційного простору РСЕС в контексті забезпечення безпеки політичного, економічного, енерго-екологічного секторів регіонального комплексу $€$ однією 3 пріоритетних задач для України та ії регіонів. До елементів наукової новизни слід віднести авторські точки зору, а саме: логіко-системна модель інформаційних потоків на мега-, мезо-, макрорівнях в умовах світового інформаційного простору; концепт-модель структури інформаційного простору для рівня регіону (модифікований варіант діаграми Дж. Венна).

\section{Література:}

1. Саввин А.С. Проблемы обеспечения информационной безопасности страны. Пятнадцатые международные Плехановские чтения. М. : РЭА им. Г. Плеханова, 2002. С. 10-18.

2. Поляков А. В. Проблематика информационной безопасности в экономических научных направлениях. Теория и практика общественного развития, 2011. №6. С. 72-74.

3. Немиткина В.В. Применение методов оптимизации при анализе и управлении информационными рисками. Экономика и математические методы, 2008. Т. 44, №2. С. 100-107.

4. Буханцева Н.В. Методология исследования информационного пространства. Educational Technology \& Society 14(2) 2011. - http://ifets.ieee.org/russian/depository/v14_i2/pdf/8r.pdf (дата звернення: 19.02.2019).

5. Баутов А.Н. Экономический взгляд на проблемы информационной безопасности. 2002 . URL: https://www.osp.ru/os/2002/02/181118/ (дата звернення: 19.02.2019).

6. Петренко С. А., Симонов С. В. Управление информационными рисками. Экономически оправданная безопасность. М. : Компания АйТи: ДМК Пресс, 2004. 384 с.

7. Дубров А. М., Лагоша Б. А., Хрусталев Е. Ю., Барановская Т. П. Моделирование рисковых ситуаций в экономике и бизнесе. М.: Финансы и статистика, 2001. 176 с.

8. Бурдин О.А., Кононов А.А. Комплексная экспертная система управления информационной безопасностью "АванГард". Информационное общество, 2002. № 3. С. 38-44.

9. Дудатьев А. В. Метод управления комплексной информационной безопасностью. Ukrainian Scientific Journal of Information Security. 2015. vol. 21, issue 2, p. 207-212.

10. Саввин А. С. "Новая экономика" в России и СНГ. Межвузовский сб. науч. тр. М., 2002, №14. С. 14-31.

11. Михайлов Д. В. Концептуальная модель информационной безопасности предприятия. Віснок СНУ ім. В. Даля, 2013, №4 (193), ч.2. С. 114-118.

12. Домарев В. В. Безопасность информационных технологий. Системный подход. К. : ООО гИД "ДС", 2004. 992 с.

13. Калинина А. Э. Развитие информационного пространства региональной хозяйственной системы : монография. Волгоград : из-во ВолГУ, 2005. $357 \mathrm{c}$.

14. Кузнецов Н. А. О развитии фундаментальных исследований по информационному взаимодействию в природе и обществе. Проблемы передачи информации, 1997. Т 33, Вып. 3. С. 111-112.

15. Левич А. П. Информация как структура систем. Семиотика и информатика, 1978, №10. С. 116-132.

16. Антопольський А. Б. Методические вопросы инвертизации информационных ресурсов. Сб. науч. mp. "EBA-2004". М., 2004. С. 23-28.

17. Химмельблау Д. Прикладное нелинейное. М.: Мир, 1975. 536 с.

18. Азроянц Э. А. Глобализация: как научная проблема. Полигнозис, 2002. №4. С. 9-14.

\section{References:}

1. Savvin, A. S. (2002). Problems of information security of the country. Pyatnadtsatyn mezhdunarodnye Plekhanovskie chteniya. M.: REA im. G. Plekhanova, 10-18 [in Russ.].

2. Polyakov, A. V. (2011). Problems of information security in economic research areas. Theory and practice of social development, 6, 72-74 [in Russ.].

3. Nemitkina, V. V. (2008). Application of optimization techniques in the analysis and management of risk ifnormation. Economics and mathematical methods, 44(2), 100-107 [in Russ.]. 
4. Bukhantseva, N. V. (2011). The methodology of the research information space. Educational Technology \& Society, 14(2). Retrieved from http://ifets.ieee.org/russian/depository/v14_i2/pdf/8r.pdf [in Russ.].

5. Bautov, A. N. (2002). Ekonomicheskiy vzglyad na problemy informatsionnoy bezopasnosti. Retrieved from https://www.osp.ru/os/2002/02/181118/ [in Russ.].

6. Petrenko, S. A. \& Simonov, S. V. (2004). Information risk management. Economically justified security. M. : Kompaniya AyTi: DMK Press. [in Russ.].

7. Dubrov, A. M., Lagosha, B. A., Khrustalev, Ye. Yu. \& Baranoskaya, T. P. (2001). Modelirovanie riskovykh situatsiy $v$ ekonomike i biznese [Modeling of risk situations in economy and business]. M. : Finansy i statistika [in Russ.].

8. Burdin, O. A. \& Kononov, A. A. (2002). Integrated expert system for information security management "Avant-garde". Informatsionnoe obshchestvo, 3, 38-44 [in Russ.].

9. Dudatev, A. V. (2015). A method of managing complex information security. Ukrainian Scientific Journal of Information Security, 21(2), 207-212 [in Russ.].

10. Savvin, A. S. (2002). The "new economy" in Russia and the CIS. Mezhvuzovskiy sb. nauch. tr. M., 14, 14-31 [in Russ.].

11. Mikhaylov, D. V. (2013). Conceptual model of enterprise information security. Visnok SNU im. V. Dalya, 4 (193), 2, 114-118 [in Russ.].

12. Domarev, V. V. (2004). Bezopasnost informatsionnykh tekhnologiy. Sistemnyy podkhod [Information technology security. System approach]. K.: OOO GID "DS" [in Russ.].

13. Kalinina, A. E. (2005). Razvitie informatsionnogo prostranstva regionalnoy khozyaystvennoy sistemy [Development of information space of regional economic system: monograph]. Volgograd: iz-vo VolGU [in Russ.].

14. Kuznetsov, N. A. (1997). On the development of fundamental research on information interaction in nature and society. Problemy peredachi informatsii, 33(3), 111-112 [in Russ.].

15. Levich, A. P. (1978). Information as system structure. Semiotika i informatika, 10, 116-132 [in Russ.].

16. Antopolskiy, A. B. (2004). Methodological issues of information resources inversion. Sb. nauch. tr. "YeVA-2004", 23-28 [in Russ.].

17. Khimmelblau, D. (1975). Prikladnoe nelineynoe programmirovanie [Applied nonlinear programming]. M. : Mir [in Russ.].

18. Azroyants, E. A. (2002). Globalization: as a scientific problem. Polignozis, 4, 9-14 [in Russ.]. 